\title{
Pengaruh Terapi Tertawa Dengan Media Menonton Video Stand-Up Comedy Terhadap Kecemasan Mahasiswa Keperawatan Semester I Menjelang UAS Di STIKes Buleleng
}

\author{
Komang Putri Wahyuni', G. Nur Widya Putra', I Km Gde Trisna Purwantara,S.E., M.M² \\ ${ }^{1}$ Program Studi S1 Keperawatan, Sekolah Tinggi ilmu Kesehatan Buleleng, komangputriw@gmail.com
}

\section{INFO ARTIKEL}

\section{Riwayat Artikel:}

Diterima: 28 Mei 2020

Disetujui: 20 Juli 2020

\section{Kata Kunci:}

Tertawa

Kecemasan

Video

\section{A. LATAR BELAKANG}

Mahasiswa dinilai memiliki tingkat intelektualitas yang tinggi, kecerdasan dalam berpikir dan bertindak.

\begin{abstract}
Abstrak: Kecemasan adalah sebagai suatu keadaan dimana seorang merasa tidak nyaman dan adanya tekanan sistem saraf otonom dalam aktivitas rangsang akibat ancaman yang tidak diketahui. Kecemasan sendiri berpengaruh terhadap performa dari orang yang mengalaminya, contohnya penurunan prestasi akademik dari mahasiswa. Salah satu alternative untuk mengatasi kecemasan yakni dengan terapi tertawa. Penelitian ini bertujuan .untuk menganalisis Pengaruh Terapi Tertawa Dengan Media Menonton Video Stand Up Comedy Terhadap Kecemasan Mahasiswa Keperawatan Semester I Menjelang UAS di STIKes Buleleng. Desain penelitian ini yaitu pra eksperimental dengan rancangan one group pre dan post-test design. Besar sampel yang digunakan yaitu 51 responden yang telah dipilih dengan menggunakan teknik purposive sampling. Pengumpulan data dilakukan menggunakan lembar kuesioner HARS (Hamilton Anxiety Rating Scale). Penelitian ini menggunakan uji Wilcoxon dengan taraf signifikan $\alpha=$ o,05. Didapatkan hasil data nilai rata-rata pre 17.86 dan nilai rata-rata post 6.24. Hasil uji menggunakan uji Wilcoxon didapatkan nilai $p(0,000)<a$ $(\mathrm{o}, 05)$, artinya $\mathrm{H}_{\mathrm{o}}$ ditolak dan $\mathrm{H}_{\mathrm{a}}$ diterima. Sehingga dapat disimpulkan bahwa terdapat pengaruh terapi tertawa terhadap kecemasan mahasiswa keperawatan semester I menjelang UAS di STIKes Buleleng.
\end{abstract}

\begin{abstract}
Anxiety is a condition where a person feel uncomfortable and have pressure on the autonomic nervous system in stimulating activity due to unknown threats. Anxiety itself affects the performance of people who experience it, for example the decline in academic achievement of students. One alternative to overcome anxiety is with laughing therapy. This study aims to analyze The Effect of Laughing Therapy on Media Watch Stand Up Comedy Video Towards Nursing Students First Semester Anxiety Before Final Test in STIKes Buleleng. The design of this study was pre-experimental with the design of one group pre and post-test design. The sample size used 51 respondents who selected by using purposive sampling technique. Data collection was done by using questionnaire HARS (Hamilton Anxiety Rating Scale). This study used Wilcoxon test with a significant level of a $=0.05$. Obtain data from the pre-average value of 17.86and post-average value of 6.24. The test result by using Wilcoxon test obtained a value of $p(0,000)<\alpha(0.05)$, meaning that $H_{o}$ rejected and Ha is accepted. So it can be concluded that there is an effect of laughter therapy on the anxiety of nursing students in the first semester before UAS at STIKes Buleleng.
\end{abstract}

Berpikir kritis dan bertindak dengan cepat dan tepat merupakan sifat yang cenderung melekat pada diri sehingga saling melengkapi [1]. Mahasiswa juga 
merupakan salah satu kelompok masyarakat yang rentan terhadap masalah kesehatan mental [2]. Didukung dengan temuan yang menunjukkan bahwa diantara seluruh mahasiswa yang mencari pelayanan konseling, masalah utama yang sering muncul ialah kecemasan, kemudian disusul masalah terkait akademik dan kerja [3]. Menurut WHO (2017) populasi global dengan gangguan kecemasan diperkirakan 3,6\%, jumlah ini meningkat sebesar $14,9 \%$. Di Indonesia populasi yang mengalami gangguan kecemasan adalah 3,3\% dari total populasi. Terkait dengan mahasiswa dilaporkan bahwa 25\% mahasiswa mengalami cemas ringan, 60\% mengalami cemas sedang, dan $15 \%$ mengalami cemas berat [4]. Menurut Widodo, kecemasan bukan saja bergantung pada variabel manusianya tetapi juga rangsang yang membangkitkan kecemasan [5]. Dalam hal ini salah satu rangsang yang membangkitkan kecemasan adalah situasi saat ujian, timbulnya kecemasan yang paling besar adalah pada saat mahasiswa menghadapi tes atau ujian [3] Hal ini biasanya terjadi pada mahasiswa baru yang mempunyai beban berbeda dengan kebiasaan $\mathrm{p}$ ada sekolah tingkat atas sebelum masuk pada perguruan tinggi. Hal ini membutuhkan keterampilan diri dalam menyesuaikan diri dengan lingkungan baru di perguruan tinggi [6]. Hal ini terkait dengan mahasiswa yang mengalami masalah psikologis dan juga pengaruhnya terhadap prestasi akademik (performa belajar) mahasiswa tersebut [7].

Penanganan cemas dapat dilakukan dengan terapi farmakologi maupun terapi non farmakologi [8]. Obat anti cemas menimbulkan efek samping antara lain yaitu mengantuk, kinerja psikomotor dan kemampuan kognitif menurun, penglihatan kabur, konstipasi, sinus takikardi, perubahan EKG, hipotensi, tremor halus dan agitasi [9]. Obat-obatan ini akan berdampak kurang baik bila dikonsumsi terus menerus [10]. Untuk mengurangi efek farmakologi, terapi non farmakologi merupakan intervensi yang cocok digunakan untuk mengurangi kecemasan, salah satu contoh terapi non farmakologi yang dapat digunakan adalah terapi tertawa [11].

Tertawa adalah kegiatan yang tidak menggunakan biaya namun dapat membuat pikiran menjadi santai dan tidak terbeban oleh masalah dan juga kegiatan ini juga bermanfaat dalam mencegah terjadinya penyakit. Menurut Alvin Nursalim, tertawa diyakini memberikan dua manfaat sekaligus pada manusia. Manfaat sehat yang pertama adalah untuk kesehatan fisik dan mental, manfaat yang kedua adalah tertawa memberikan memberikan kesehatan jiwa dan raga [12]. Menurut Zulkarnian \& Ferry Novliadi (2014) dengan judul penelitian Sense of Humor dan Kecemasan
Menghadapi Ujian di Kalangan Mahasiswa menunjukkan bahwa ada hubungan negatif antara sense of humor dengan kecemasan menghadapi ujian ( $\mathrm{r}$ $=0,275 \mathrm{p} \leq 0.01)$ [13].

Salah satu jenis terapi yang bermanfaat dan dapat menimbulkan relaksasi sehingga mengurangi kecemasan yaitu terapi tertawa [14]. Terapi tertawa yang diberikan yaitu dengan media video stand-up comedy, dimana beberapa adegan lucu dapat membuat penonton tertawa. Penyertaan media video stand-up comedy dalam terapi ini dikarenakan stand-up comedy ini banyak diminati oleh semua kalangan khususnya mahasiswa. Stand-up comedy merupakan sebuah bentuk pertunjukan seni komedi yang dibawakan secara monolog oleh seorang komika. Komika adalah seseorang yang hidup menjadi lucu lewat menceritakan lelucon [15] .

Berdasarkan penelitian Anissa dan kawan-kawan, hasil penelitian menunjukkan tingkat kecemasan yang dirasakan mahasiswa yaitu tidak mengalami kecemasan (26.4\%), kecemasan ringan (27.6\%), kecemasan sedang (32.2\%), kecemasan berat (13.0\%), dan kecemasan sangat berat $(0.8 \%)$ [3]. Masa studi atau tingkat semester mahasiswa berhubungan dengan tingkat kecemasan mahasiswa $(p<0.05)$. Studi pendahuluan yang dilakukan di Sekolah Tinggi Ilmu Kesehatan (STIKes) Buleleng pada tanggal 18 Oktober 2019 berpedoman pada HARS (Hamilton Anxiety Rate Scale). Dari 10 mahasiswa yang diobservasi secara acak, kemudian didapatkan data tingkat kecemasan mahasiswa yaitu kecemasan ringan (5 orang), kecemasan sedang (3 orang), dan kecemasan berat (2 orang). Hasil wawancara yang dilakukan peneliti terhadap mahasiswa di Sekolah Tinggi Ilmu Kesehatan (STIKes) Buleleng, kebanyakan dari mahasiswa tersebut mengatakan saat cemas terjadi, mahasiswa tersebut mengalami sakit kepala, mudah tersinggung, membengongkan diri, nafsu makan berkurang. Berdasarkan uraian diatas, maka peneliti tertarik melakukan penelitian tentang pengaruh terapi tertawa dengan media menonton video stand-up comedy terhadap kecemasan mahasiswa keperawatan Semester I di STIKes Buleleng.

\section{B. METODE PENELITIAN}

Pendekatan yang digunakan pada penelitian ini adalah penelitian kuantitatif yang menggunakan desain penelitian one group pre-test and pos-test yaitu dengan metode purposive sampling, yaitu teknik penetapan sampel dengan cara memilih sampel dari populasi sesuai dengan keinginan peneliti yang dapat mewakili karakteristik populasi. Sebelum diberikan intervensi, http://ejournal.stikesbuleleng.ac.id/index.php/Midwinerslion|259 
sampel responden akan di minta untuk melakukan pretest dengan menggunakan lembar kuisioner (Hamilton
Anxiety Rating Scale). Tes ini bertujuan untuk mengukur kecemasan pada mahasiswa.

TABEL 1

Definisi Operasional Pengaruh Terapi Tertawa Dengan Media Menonton Video Stand Up Comedy Terhadap Kecemasan Mahasiswa Keperawatan Semester I Di STIKes Buleleng.

\begin{tabular}{|c|c|c|c|c|c|}
\hline Variabel & Definisi Operasional & Parameter & Alat Ukur & Skala Ukur & Hasil Ukur \\
\hline $\begin{array}{c}\text { Bebas: } \\
\text { Terapi tertawa }\end{array}$ & $\begin{array}{l}\text { Terapi tertawa adalah Terapi untuk } \\
\text { menghilangkan kecemasan dengan } \\
\text { cara tertawa menggunakan suatu } \\
\text { media }\end{array}$ & $\begin{array}{c}\text { Diberikan } 3 \text { kali selama } 1 \\
\text { minggu }\end{array}$ & $\begin{array}{c}\text { SOP Terapi } \\
\text { tertawa }\end{array}$ & - & - \\
\hline $\begin{array}{l}\text { Terikat: } \\
\text { Kecemasan } \\
\text { pada } \\
\text { mahasiswa }\end{array}$ & $\begin{array}{l}\text { Kecemasan merupakan respon } \\
\text { psikologi tubuh terhadap hal baru yang } \\
\text { dapat memperingatkan individu } \\
\text { terhadap bahaya yang akan terjadi }\end{array}$ & $\begin{array}{l}\text { Dilakukan dengan kuesioner } \\
\text { Hamilton Anxiety Rating } \\
\text { Scale (HARS) untuk menilai } \\
\text { kecemasan pada mahasiswa }\end{array}$ & $\begin{array}{l}\text { Kuesioner } \\
\text { Hamilton } \\
\text { Anxiety } \\
\text { Rating Scale } \\
\text { (HARS) }\end{array}$ & Ordinal & $\begin{array}{l}\text { Tidak } \\
\text { mengalami } \\
\text { kecemasan } \\
(\leq 14) \\
\text { Kecemasan } \\
\text { Ringan }(14-20) \\
\text { Kecemasan } \\
\text { sedang }(21-27) \\
\text { Kecemasan } \\
\text { berat }(28-41) \\
\text { Panik }(42-56)\end{array}$ \\
\hline
\end{tabular}

Hipotesis nol $\left(\mathrm{H}_{\mathrm{o}}\right)$ bersifat sebab atau akibat, dan pada penelitian ini digunakan hipotesis nol yaitu tidak ada pengaruh terapi tertawa dengan media menonton video stand up comedy terhadap kecemasan mahasiswa keperawatan semester I di Sekolah Tinggi Ilmu Kesehatan (STIKes) Buleleng. Sedangkan hipotesis alternatif $\left(\mathrm{H}_{\mathrm{a}}\right)$ yang digunakan yaitu adanya pengaruh terapi tertawa dengan media menonton video standup comedy terhadap kecemasan mahasiswa keperawatan semester I di Sekolah Tinggi Ilmu Kesehatan (STIKes) Buleleng.

Definisi operasional merupakan uraian tentang batasan variabel yang dimaksud, atau tentang apa yang diukur oleh variabel yang bersangkutan. Untuk penelitian ini, definisi operasional yang digunakan sesuai dengan Tabel 1. Hal ini bermanfaat untuk mengarahkan kepada pengukuran atau pengamatan terhadap variabel-variabel yang bersangkutan serta pengembangan instrumen [16].

Alat pengumpulan data yang digunakan dalam penelitian adalah Standard Operational Procedure (SOP) terapi tertawa dan lembar kuisioner (Hamilton Anxiety Rating Scale). Prosedur ini dilaksanakan dengan cara pemberian terapi tertawa dengan menggunakan media film Stand Up Comedy (Bondres Rare Kual) berdurasi 20-30 menit selama 3 kali dalam satu minggu. Sedangkan lembar kuisioner (Hamilton Anxiety Rating Scale) digunakan untuk mengetahui tingkat kecemasan pada mahasiswa, hasil pengukuran dapat dilihat dari hasil lembar kuisioner tersebut. Teknik pengolahan data yang diakukan yaitu editing, coding, entry, cleaning,dan tabulating. Data secara keseluruhan dianalisis dengan menggunakan program komputer yaitu SPSS yang meliputi analisis univariat dan analisis bivariat. Adapun analisa statistik dilakukan dengan menggunakan uji Wilcoxon.

\section{HASIL DAN PEMBAHASAN}

\section{Hasil Analisis Data}

Penelitian ini dilaksanakan di STIKes Buleleng yang memiliki mahasiswa sejumlah 462 orang. Sebanyak 51 orang mahasiswa yang mengalami kecemasan dijadikan sebagai subjek penelitian dan data yang diambil menggunakan teknik Non Probability Sampling tepatnya purposive sampling. Ada beberapa karakteristik responden yang diteliti yaitu meliputi usia, jenis kelamin dan pendidikan SMA.

\section{TABEL 2}

Distribusi Responden Berdasarkan Usia Mahasiswa Keperawatan Semester I di STIKes Buleleng

\begin{tabular}{llllllll} 
Variabel & N & Mean & Min & Max & SD & 95\%CI & \\
\hline Usia & 51 & 18.41 & 18 & 20 & 0.669 & $\begin{array}{l}17.76 \\
19.05\end{array}$ & - \\
& & & & & & &
\end{tabular}


Dilihat dari karakteristik responden dari total 51 mahasiswa usia termuda 18 tahun dan usia tertua 20 tahun. Pendapat tersebut sejalan penelitian oleh Nabila dan kawan-kawan dengan menyatakan bahwa ada hubungan yang bermakna antara umur dengan tingkat kecemasan [17].

TABEL 3

Distribusi Responden Berdasarkan Jenis Kelamin Mahasiswa Keperawatan Semester I di STIKes Buleleng

\begin{tabular}{ccc}
\hline Jenis & Frekuensi & Persentase \\
\hline Laki-laki & 16 & 31.4 \\
Perempuan & 35 & 68.6 \\
\hline JUMLAH & 51 & 100
\end{tabular}

Berdasarkan data dari 51 orang responden (pada Tabel 4), sebagian besar responden ini berjenis kelamin perempuan dengan jumlah 35 orang. Sedangkan karakteristik responden berdasarkan pendidikan saat jenjang SMA menunjukkan bahwa jurusan kesehatan dan IPA sangat dominan dibandingkan dengan nonkesehatan.

\section{TABEL 4}

Distribusi Responden Berdasarkan Pendidikan SMA Mahasiswa Keperawatan Semester I di STIKes Buleleng

\begin{tabular}{lllll}
\hline Variabel & $\mathbf{N}$ & Kesehatan & $\begin{array}{l}\text { Non- } \\
\text { Kesehatan }\end{array}$ & $\begin{array}{l}\text { Jurusan } \\
\text { IPA }\end{array}$ \\
\hline Sekolah & $\mathbf{5 1}$ & $\mathbf{1 9}$ & 7 & $\mathbf{2 5}$ \\
\hline
\end{tabular}

Kemudian, analisa data dilakukan dengan tujuan untuk mengidentifikasi dari variabel yang diteliti secara terpisah dengan cara membuat tabel frekuensi dari msing-masing variable penelitian pre-test dan post-test. Tabel 5 menunjukkan data sebelum responden diberikan terapi tertawa menjelang masa ujian akhir semester (UAS). Dari hasil ini terlihat bahwa ada 9 orang yang mengalami kecemasan berat sedangkan mengalami kecemasan ringan dan sedang berturut-turut adalah 27 orang dan 15 orang. Hasil ini sesuai dengan penelitian yang pernah dilakukan oleh Made Ruspawan dan Desi dengan judul "Pengaruh Terapi Tertawa Terhadap Tingkat Kecemasan Pada Lanjut Usia di PSTW Wana Seraya Denpasar". Tingkat kecemasan pada lanjut usia sebelum diberikan terapi tertawa di PSTW Wana Seraya Denpasar dapat diketahui bahwa responden di PSTW Wana Seraya Denpasar yang mengalami kecemasan sebanyak 27 orang dengan jumlah kecemasan ringan 24 orang (88,9 \%). Sedangkan, responden yang mengalami kecemasan sedang sebanyak 3 orang $(11,1 \%)$ [18].

TABEL 5

Distribusi Kategori Kecemasan Mahasiswa Keperawatan Semester I Sebelum Diberikan Terapi Tertawa di STIKes Buleleng

\begin{tabular}{cccc}
\hline \multicolumn{2}{c}{ Kategori } & Frekuensi (N) & Persentase (\%) \\
\hline Normal & $(<6)$ & 0 & 0 \\
Ringan & $(6-14)$ & 27 & 52.9 \\
Sedang & $(15-27)$ & 15 & 29.4 \\
Berat & $(>27)$ & 9 & 17.6 \\
\hline \multicolumn{2}{c}{ JUMLAH } & 51 & 100 \\
\hline
\end{tabular}

Berdasarkan Tabel 6, dapat dilihat bahwa dari total 51 orang responden yang menjadi subjek penelitian, rata-rata (mean) skor kecemasan mahasiswa sebelum pemberian Terapi Tertawa adalah 17.86 (95\%CI ; 17.21 - 18.50) dengan nilai standard deviation 8.672. Nilai terendah dengan kode 2 dan nilai tertinggi dengan kode 4. Dari estimasi interval disimpulkan bahwa 95\% diyakini bahwa rata-rata nilai skor kecemasan mahasiswa, yaitu diantara 17.21 sampai dengan 18.50 .

TABEL 6

Skor Pre-Test di STIKes Buleleng

\begin{tabular}{lllllll} 
Variabel & N & Mean & Min & Max & SD & 95\%CI \\
\hline Pre Test & 51 & 17.86 & 6 & 38 & 8.672 & $17.21-18.50$ \\
\hline
\end{tabular}

Tabel 7 merupakan data yang menunjukkan tingkat kecemasan responden setelah diberikan terapi tertawa. Dari data ini, terlihat bahwa sebagian besar responden memiliki kecemasan yang normal (38 orang, sedangkan kecemasan ringam dan berat sejumlah 9 dan 4 orang berturut-turut. Kecemasan pada tingkat berat berkurang dibandingkan saat dilakukan pre-test.

TABEL 7

Distribusi Kategori Kecemasan Mahasiswa Keperawatan Semester I Sesudah Diberikan Terapi Tertawa di STIKes Buleleng.

\begin{tabular}{cccc}
\hline \multicolumn{2}{c}{ Kategori } & Frekuensi (N) & Persentase (\%) \\
\hline Normal & $(<6)$ & 38 & 74.5 \\
Ringan & $(6-14)$ & 9 & 17.6 \\
Sedang & $(15-27)$ & 4 & 7.8 \\
Berat & $(>27)$ & 0 & 0 \\
\hline \multicolumn{2}{c}{ JUMLAH } & 51 & 100 \\
\hline
\end{tabular}

Berdasarkan data pada Tabel 8 dapat dilihat bahwa dari 51 orang total responden yang menjadi subjek penelitian rata-rata (mean) skor kecemasan mahasiswa sesudah pemberian terapi tertawa adalah

http://ejournal.stikesbuleleng.ac.id/index.php/Midwinerslion | 261 
6.24 (95\%CI: 5.59-6.88) dengan nilai standard deviation sebesar 4.71. Nilai terendah dengan kode 1 dan nilai tertinggi dengan kode 3, lalu dari estimasi interval disimpulkan bahwa 95\% diyakini bahwa ratarata nilai skor kecemasan mahasiswa, yaitu diantara 5.59 sampai dengan 6.88.

\section{TABEL 8}

Skor Post-Test di Di STIKes Buleleng

\begin{tabular}{cllllll}
\hline Variabel & N & Mean & Min & Max & SD & 95\%CI \\
\hline Post Test & 51 & 6.24 & 1 & 24 & 4.71 & $5.59-6.88$ \\
\hline
\end{tabular}

Uji yang dilakukan dengan menggunakan uji Wilcoxon menunjukkan bahwa sig.(2-tailed) atau nilai $p$ memiliki nilai o,oo6 (Tabel 9). Nilai $p$ ini lebih kecil dari tingkat sigifikansi yang telah ditetapkan yaitu 0.05 (a) sehingga hipotesis nol $\left(\mathrm{H}_{0}\right)$ ditolak dan hipotesis alternatif $\left(\mathrm{H}_{\mathrm{a}}\right)$ diterima. Hal ini menunjukkan bahwa terdapat pengaruh terapi tertawa dengan media menontn video standup comedy terhadap tingkat kecemasan responden menjelang ujian akhir semester (UAS).

\section{TABEL 9}

Hasil Uji Pre dan Post Test dengan menggunakan Uji Wilcoxon

\section{Terapi Tertawa pre dan post}

$\begin{array}{lll}\text { N } & \text { Z } & \text { P.Value } \\ 51 & -6.219 & \text { 0.006 }\end{array}$

\section{Pengaruh Terapi Tertawa Dengan Media Menonton Video Stand Up Comedy Terhadap Kecemasan Mahasiswa Keperawatan Semester I di STIKes Buleleng}

Tingginya tingkat kecemasan mahasiswa keperawatan semester pertama menurut sebagian besar responden disebabkan oleh persiapan responden menjelang UAS yang masih dirasa kurang. Selain itu, kecemasan juga dirasakan karena ujian dilaksanakan dengan berbasis komputer sehingga hasil ujian akan langsung diketahui. Mahasiswa merasa takut dan malu jika nilai yang mereka dapatkan ada di bawah nilai ratarata. Berdasarkan penelitian yang dilakukan oleh Widyastuti, metode analisis data yang dilakukan dalam penelitian ini menggunakan fasilitas program SPSS versi 11.05 untuk menguji apakah ada pengaruh terapi tawa terhadap kecemasan ada narapidana [19]. Uji T yang digunakan menunjukkan adanya pengaruh yang sangat signifikan terapi tawa terhadap penurunan kecemasan pada narapidana, hal ini terlihat dari nilai $t=7,102$. Sehingga hipotesis penelitian diterima. Selain itu, berdasarkan penelitian oleh Ratna Yunita pada tahun 2018 dengan judul "Perbedaan Tingkat Kecemasan Pada Mahasiswa Baru Di Fakultas Ilmu Kesehatan dan Non Fakultas Ilmu Kesehatan Universitas Aisyiyah Yogyakarta”, didapatkan hasil penelitian yang menunjukkan mahasiswa baru di Fakultas Ilmu Kesehatan (FIKES) lebih cemas dan lebih depresif dibandingkan dengan Non (FIKES)/FEISHum (NSQ $\mathrm{t}=$ $-3.328, p=0.002$ dan BDI $=2.410, p=0.019$ ). Peneliti menyimpulkan terdapat perbedaan kecemasan dan depresi antara mahasiswa baru di FIKES dan Non FIKES dimana mahasiswa baru di FIKES lebih cemas dan depresif daripada mahasiswa baru di Non FIKES [20].

Seperti yang telah dijelaskan sebelumnya, kecemasan merupakan keadaan yang dimana timbul perasaan yang tidak menyenangkan disertai dengan sensasi fisik yang dapat memperingatkan individu terhadap bahaya yang akan datang. Keadaan ini sering kabur tetapi kecemasan itu sendiri selalu dirasakan. Untuk mengurangi kecemasan dapat dilakukan dengan berbagai hal salah satunya dengan terapi tertawa. Terapi tertawa merupakan salah satu metode alternatif yang sering digunakan untuk mengatasi tingkat kecemasan. Ada beberapa jenis terapi alternatif yang tepat untuk mengatasi kecemasan antara lain relasaksi, gerakan yoga dan humor yang dapat mengurangi ansietas.

Setelah melakukan penelitian dan memberikan perlakuan berupa terapi tertawa selama satu minggu sebanyak 3 kali kepada responden, kecemasan mahasiswa menurun signifikan. Hal tersebut dibuktikan dengan hasil post-test yang didapatkan hasil 38 responden $(74.5 \%)$ tidak mengalami kecemasan. Jadi, dapat disimpulkan bahwa terapi tertawa dapat mempengaruhi tingkat kecemasan mahasiswa keperawatan semester I menjelang UAS di STIKes Buleleng. Meskipun penelitian ini sesuai dengan hipotesis alternatif yang diajukan, penelitian ini tetap memiliki banyak kekurangan serta ketidaksempurnaan yang ada didalamnya. Salah satunya terdapat dalam proses penelitiannya dimana waktu penayangan video standup comedy yang terlalu lama dan video yang diberikan tidak difokuskan pada hal-hal yang dapat membuat tertawa.

\section{SIMPULAN DAN SARAN}

Dari pembahasan yang telah dipaparkan pada subbab sebelumnya, maka dapat disimpulkan sebagai berikut.

1. Berdasarkan variabel usia, responden dengan usia termuda dan usia tertua adalah 18 tahun http://ejournal.stikesbuleleng.ac.id/index.php/Midwinerslion | 262 
dan 20 tahun berturut-turut, dan rata-rata (mean) usia responden adalah 18.41.

2. Berdasarkan jenis kelamin, responden yang berjumlah 51 orang terdiri dari laki-laki sebanyak 16 orang dan perempuan sebanyak 35 orang. Berdasarkan latar belakang pendidikan SMA, responden berasal latar belakang jurusan IPA (25 orang), kesehatan (19 orang), dan nonkesehatan (9 orang).

3. Dari 51 mahasiswa yang menjadi responden didapatkan data yang menunjukkan bahwa sebelum diberikan Terapi Tertawa responden yang memiliki kecemasan ringan 27 orang, kecemasan sedang 15 orang, kecemasan berat 9 orang. Sebagian besar responden mengalami tingkat kecemasan ringan. Rata-rata (mean) skor kecemasan mahasiswa sebelum pemberian Terapi Tertawa adalah 17.86 (95\%CI ; 17.2118.50), standard deviation 8.672, nilai terendah dengan kode 2 dan nilai tertinggi dengan kode 4 . Dari estimasi interval disimpulkan bahwa $95 \%$ diyakini bahwa rata-rata nilai skor kecemasan mahasiswa, yaitu diantara 17.21 sampai dengan 18.50 .

4. Sedangkan data sesudah diberikan Terapi Tertawa menunjukkan mahasiswa yang memiliki kecemasan normal 38 orang, kecemasan sedang 4 orang, dan kecemasan sedang o orang. Sebagian besar mengalami tingkat kecemasan rendah. Rata-rata (mean) skor kecemasan mahasiswa sesudah pemberian terapi tertawa adalah 6.24 (95\%CI: 5.59-6.88), nilai standard deviation 4.71, nilai terendah dengan kode 1 dan nilai tertinggi dengan kode 3 dari estimasi interval disimpulkan bahwa $95 \%$ diyakini bahwa rata-rata nilai skor kecemasan mahasiswa, yaitu diantara 5.59 sampai dengan 6.88.

5. Berdasarkan hasil uji yang dilakukan dengan menggunakan uji Wilcoxon maka dapat disimpulkan bahwa terdapat Pengaruh Terapi Tertawa dengan Media Menonton Video Stand Up Comedy Terhadap Kecemasan Mahasiswa Semester I Menjelang UAS di STIKes Buleleng.

Hasil yang didapatkan dalam penelitian ini diharapkan dapat menambah pengetahuan kepada peserta didik dan institusi pendidikan tentang Pengaruh Terapi Tertawa Dengan Media Menonton Video Stand Up Comedy Terhadap Kecemasan Mahasiswa Keperawatan Semester I Menjelang UAS. Selain itu, penelitian ini juga diharapkan mampu menjadi masukan bagi perawat dan tenaga kesehatan dalam menangani kecemasan pada mahasiswa serta referensi untuk meningkatkan keterampilan perawat dan tenaga medis lainnya dalam memberikan asuhan pada mahasiswa yang mengalami kecemasan. Penelitian ini juga dapat dijadikan sebagai salah satu batu loncatan dalam melakukan kajian ilmu tentang terapi tertawa untuk penanganan penyakit lain.

Dan terakhir, penelitian ini diharapkan dapat menambah wawasan serta pengetahuan mengenai pemberian terapi tertawa serta sebagai dasar ilmiah untuk melakukan penelitian selanjutnya.

\section{E. DAFTAR RUJUKAN}

[1] L. D. Lastary And A. Rahayu, "Hubungan Dukungan Sosial Dan Self Efficacy Dengan Prokrastinasi Akademik Mahasiswa Perantau Yang Berkuliah Di Jakarta," Vol. 2, No. 2, Pp. 17-23, 2018.

[2] D. A. N. W. Dan S. M. Abdullah, "Jurnal SosioHumaniora Prokrastinasi Akademik Dalam Penyelesaian Skripsi," Vol. 5, No. 1, 2016.

[3] Anissa, Suryani, And Mirwanti, “Tingkat Kecemasan Mahasiswa Keperawatan Dalam Menghadapi Ujian Berbasis Computer Based," Vol. 16, No. 2, Pp. 67-75, 2018.

[4] D. Akbar, "Hubungan Antara Tingkat Kecemasan Dengan Prestasi Akademik Mahasiswa Di Fakultas Psikologi Universitas Muhammadiyah Surakarta." Universitas Muhammadiyah Surakarta, 2015.

[5] Widodo Et Al, "Analisis Faktor Tingkat Kecemasan, Motivasi Dan Prestasi Belajar Mahasiswa,” Vol. 01, No. 01, Pp. 67-77, 2017.

[6] Ratna Yunita, "Perbedaan Tingkat Kecemasan Pada Mahasiswa Baru Di Fakultas Ilmu Kesehatan Dan Non Fakultas Ilmu Kesehatan Universitas ' Aisyiyah Yogyakarta," Vol. 6, 2018.

[7] Lallo, Kandou, And Munayang, "Hubungan Kecemasan Dan Hasil Uas-1 Mahasiswa Baru Fakultas Kedokteran Universitas Sam Ratulangi Manado Tahun Ajaran 2012 / 2013," Pp. 1-10, 2015.

[8] R. I. Suyanto, "Kecemasan Mahasiswa Perawat Sebelum Mengikuti Ujian Ketrampilan Di Laboratorium,” Vol. 11 No, Pp. 97-103, 2018.

[9] A. R. Cut, "Pengaruh Terapi Tertawa Terhadap Tingkat Kecemasan Pada Lansia Di Kelurahan Surau Gadang Kota Padang Tahun 2016.” Universitas Andalas, 2017.

[10] D. Hawari, "Manajemen Stres Cemas Dan Depresi Edisi Kedua," Jakarta Fkui, 2011.

[11] M. Kataria, "Laugh For No Reason (Terapi Tawa)," Jakarta Pt Gramedia Pustaka Utama, 2004.

[12] A. Nursalim, "Tertawa, Cara Sehat Yang Murah Dan Kaya Manfaat," 2014. [Online]. Available: Https://Www.Klikdokter.Com/Info-

Sehat/Read/2696074/Tertawa-Cara-Sehat-YangMurah-Amp-Kaya-Manfaat.

[13] F. Novliadi, "Sense Of Humor Dan Kecemasan Menghadapi Ujian Di Kalangan Mahasiswa," No. March, 2010.

[14] A. R. Prasetyo And H. Nurtjahjanti, "Pengaruh Penerapan Terapi Tertawa Terhadap Penurunan http://ejournal.stikesbuleleng.ac.id/index.php/Midwinerslion | 263 
Tingkat Stress Kerja Pada Pegawai Kereta Api,” $J$. Psikol. Undip, Vol. 11, 2012.

[15] R. Papana, Kitab Suci: Kiat Tahap Awal Belajar Stand Up Comedy Indonesia. Mediakita, 2012.

[16] Notoatmodjo, Metodologi Penelitin Kesehatan. Jakarta: Rineka Cipta, 2012.

[17] D. D. Nabilah, Y. Susanti, And Y. Andriane, "Perbedaan Tingkat Kecemasan Sebelum Menghadapi Ujian Sooca Pada Mahasiswa Fakultas Kedokteran Universitas Islam Bandung," Vol. 1, No. 22, Pp. 73-77, 2017.

[18] Made Ruspawan \& Desi Wulandari, "Pengaruh Terapi
Tertawa Terhadap Tingkat Kecemasan Pada Lanjut Usia Di Pstw Wana Seraya Denpasar,” Pp. 1-9, 2017.

[19] C. Widyastuti, "Pengaruh Terapi Tawa Terhadap Penurunan Kecemasan Pada Narapidana,” Vol. 7, Pp. 22-30, 2019.

[20] R. Y.S. Subardjo, "Perbedaan Tingkat Kecemasan Pada Mahasiswa Baru Di Fakultas Ilmu Keseharan Dan Non Fakultas Ilmu Kesehatan Universitas Aisyiyah Yogyakarta," J. Psikol. Integr., Vol. 6, No. 1, Pp. 18-28, 2018. 